\title{
Challenges to European Integration: Missions and Instruments ${ }^{1}$
}

\author{
TAMÁS SZEMLÉR
}

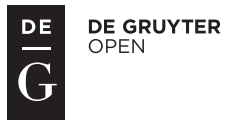

Politics in Central Europe (ISSN: 1801-3422)

Vol. 14, No. 1

DOI: 10.2478/pce-2018-0004

\begin{abstract}
The aim of this article is to highlight challenges to European integration by raising key concerns and generating debate about potential responses. This discussion is intended to be a starting point for further research and the development of more policy-specific recommendations to tackle these challenges successfully. I begin by explaining the need for a clear and realistic integration mission and then turn to the example of the Economic and Monetary Union (EMU), one of the most tangible achievements of European integration policy. The EMU also highlights the critical importance of clarity and realism in any approach to integration. My analysis moves next to the challenges that the EU is facing today and considers how the European Commission has evaluated and reacted to these challenges. Finally I propose some key elements of - and make the case for - a constructive practical approach.
\end{abstract}

Keywords: European Union, Economic and Monetary Union, crisis, mission, multi-speed integration, flexibility.

\section{Introduction}

The history of European integration has shown us several times that the perception of real challenges is what drives the integration process forward. Without a significant challenge, the mission of the integration process may become unclear to all or some Member States. This can endanger integration itself,

1 This work was commissioned by the National University of Public Service as part of project KÖFOP-2.1.2-VEKOP-15-2016-00001 - "Public Service Development for Establishing Good Governance" at the Ludovika workshop. 
potentially leading to partial or complete disintegration. Of course, serious challenges may also be seen as dangers, but each challenge faced and survived can strengthen the EU and so contribute to its development. The entire history of the European Monetary Union (EMU) - including not just developments in recent years but also earlier turbulence and its resolution in the 1970s - is one of the most tangible examples of this process.

Today the EU faces a number of challenges. These include insufficient social and territorial cohesion, mass immigration, negative demographic developments, questionable competitive practices and the lack of any real strategy regarding many problems in the EU's neighbourhood. These challenges are best approached as opportunities to reform - or, if required, radically change - traditional policies and approaches in these fields. In order to arrive at that point, however, we will need to open up an EU-wide political discussion of these topics and set priorities - which will, of course, mean some compromises. Based on the outcomes of this process, various mechanisms - and not only financial means - will need to be added to specific policies at the relevant (local/regional/ country/country-group/EU) level.

It is clear that this proposed approach reflects a model of multi-speed integration. While some may be afraid of this process, it must be emphasised that given the current depth of integration and the number and great variety of Member States concerned, this is the only realistic way forward. Multi-speed integration has already become a reality, however this is not a tragedy. The true tragedy would be if the integration process were ended solely for the sake of the unrealistic goal of preserving (an already non-existent) uniformity.

This article aims to tackle these issues by taking a realistic but at the same time optimistic approach. ${ }^{2}$ My objective is to propose ideas and provide a discussion that can inspire further research and the elaboration of more policy-specific recommendations. Bearing this in mind, I begin by highlighting the need for a clear and realistic mission concerning European integration and then turn to one of the most striking achievements of EU integration, the Economic and Monetary Union. The EMU, I show, exemplifies the importance of clarity and realism around the integration project. This article then considers key challenges for the European integration process today. I describe the European Commission's evaluation of and response to these challenges, and finally, propose some key elements of and arguments for a constructive practical approach.

2 This article draws on elements of my presentation "What Doesn't Kill the EU Makes the EU Stronger" based on a draft concept paper with the same title. This presentation was delivered at the 2016 ECPR General Conference at Charles University, Prague, 7-10 September, 2016. This article is a new, expanded and fully updated work. 


\section{The Need for a Mission}

Defining a mission is a critical step in the life of every institution or system; this is also true of the European integration process. Originally, the mission of the whole process was formulated based on the situation that Europe found itself in after World War II. As the first sentences of the Schuman Declaration stated, peaceful development and establishing long-term guarantees for that process were the most important objectives (see Box 1).

\section{Box 1: Thoughts on the mission of the European integration process in the beginning}

Excerpt from the Schuman Declaration of 9 May 1950:

"World peace cannot be safeguarded without the making of creative efforts proportionate to the dangers which threaten it.

The contribution which an organized and living Europe can bring to civilization is indispensable to the maintenance of peaceful relations. In taking upon herself for more than 20 years the role of champion of a united Europe, France has always had as her essential aim the service of peace. A united Europe was not achieved and we had war.

Europe will not be made all at once, or according to a single plan. It will be built through concrete achievements which first create a de facto solidarity. The coming together of the nations of Europe requires the elimination of the age-old opposition of France and Germany. Any action taken must in the first place concern these two countries."

Source: Schuman (1950).

Since then, the French-German partnership in particular has become a reality, surviving fundamental political and economic changes, including most crucially the reunification of Germany. We have also seen the conclusion of a key sectoral treaty establishing the European Coal and Steel Community followed by broader treaties on the European Economic Community and the European Atomic Energy Community.

These ties led to rapid development in the form of deepening integration with the achievement of many treaty goals in the 1950s and 1960s. In the beginning, the number of participating countries was limited, but in the 1970s, it began to grow, and today the majority of countries in Europe are included. This widening scope of integration - reflected in a series of enlargements and the appearance of candidate countries - speaks to the success of the process in different fields, which has attracted many countries that share the basic values associated with this integration.

Nevertheless, as a result of internal and external changes over this long period and the accomplishment of some of the original goals, new and unforeseen challenges have also emerged. On several occasions, these have raised 
questions about the success of the European integration process and thus the long-term sustainability of its original mission. In some cases, they have also given rise to Euroscepticism and even - since the first half of the 1980s - claims of "Eurosclerosis."

It must be noted that challenges can play a very important role in defining - and, if and when necessary, redefining - an organisation's mission. In principle, this can also happen independently of any challenges. In most cases, however, such independence is unrealistic - and pressure plays a key part in changing the status quo or even just raising the prospect of its reform. Along these lines, I would argue that both external and internal challenges have been very important in defining, and subsequently on various occasions, redefining the objectives of European integration.

Of course, such challenges can also be dangerous. To a great extent, our ability to judge whether a response to a challenge was positive or negative will depend on the timing of our observations. While a challenge judged to be too great may damage an organisation in the short and medium term, the effects could still prove positive over the longer term. European integration has a rich history of such situations including, as we will see, what is probably the most compelling example - the case of the Economic and Monetary Union.

There are, it is true, some challenges that prove lethal - but they are the exception. These challenges are also hard to identify at the outset. When it comes to European integration, pessimists have seen each new challenge facing the European Union as fatal - and yet the EU continues to exist. Furthermore, even the biggest challenges can be tackled satisfactorily if the power of the European Union (and its Member States) is applied effectively. Needless to say, this may call for adaptation, institutional changes, financial resources and - above all political will. But adaptation is crucial to the progress of the European Union: the series of adaptations that have taken place over decades of EU history can be seen as part of a learning process. ${ }^{4}$ Even if this learning can sometimes appear painfully slow, the main thing is that it occurs in the long run. And this process can be sped up under pressure.

We can also grasp the importance of challenges in defining the mission of European integration by considering those periods when these challenges were

3 Mongelli (2008) writes: “[T]he term 'Eurosclerosis' was coined to describe a pattern of high unemployment, slow job creation, low participation to the labour force and weakening overall economic growth during the 1980s and most of the 1990s [...]. Eurosclerosis contrasted with the more dynamic experience of the United States where economic expansion was accompanied by high job growth" (p. 22). The term also has somewhat different and broader political implications. It is widely thought that the period of Eurosclerosis came to an end with the adoption of the plan for a single European market - a plan that clearly offered a new vision for European integration and helped fulfil this updated mission.

4 In fact, all the treaties express at least an intention to adapt to changing conditions. For a chronological overview of treaties concluded by the European Union (and its predecessors), see http://eur-lex.europa. eu/collection/eu-law/treaties/treaties-overview.html. 
not present. These were periods when there were, of course, some unresolved tasks, but no really big internal or external problems. In these circumstances, a mission and associated challenges had to be "invented" by the leaders of the integration process, of course, taking into account past experiences and the current environment. A consensus then had to be reached among the Member States about this mission.

This consensus among the Member States is an important issue. Attaining a consensus first proved crucial during the so-called empty chair crisis of 1965, which was eventually solved by the Luxembourg compromise of $1966 .{ }^{5}$ This solution paved the way for the continuation of the integration process. With more and more Member States on the scene, however, achieving this consensus has become increasingly difficult. ${ }^{6}$

In this situation, as we have seen, adaptation is vital: there is a need for the ongoing creation of mechanisms that will allow the European integration process to forge ahead even at times when some Member States are not ready to back a particular - and potentially important - step that others would like to take. Differences between the Member States' positions and their willingness to deepen ties should not be treated as irresolvable. Rather, they must be seen as challenges that once again require us to find good responses that will enable development.

\section{An Exemplary Case: the Economic and Monetary Union}

The history of the European integration process is unique. At the same time, it cannot be said that the steps leading up to the current state and depth of integration were always easy. While the general trend has been positive, the history is full of ups and downs. This is also because in many cases, the leaders of the European integration process were able to learn from the "downs" and to turn them into "ups."

The history of the Economic and Monetary Union may best exemplify this pattern. To understand the EMU's genesis, we need to return to the tumult of the first half of the 1970s, which had swept away the original ideas of the Werner Plan. ${ }^{7}$ For a couple of years, it may have seemed that the plan had been abandoned altogether especially in view of other developments. Instead, however, what followed was the incremental development of the Economic and Monetary

5 For details of the reasons for the crisis and related background as well as its longer-term consequences, see Caraffini (2015).

6 For details of the Luxembourg compromise, see the official communications issued in January 1966 (Council of the European Economic Community 1966).

7 For details, see the full text of the Werner Plan (or Werner Report) (Council-Commission of the European Communities 1970). 
Union along with the establishment of the European Currency Unit (ECU) ${ }^{8}$ and the operation (and later reform) of the European Exchange Rate Mechanism.

A key turn in this story took place in the 1980s when France declared that it would follow la politique du franc fort ["the policy of the strong franc"], an expression that carried extra symbolic weight since "Francfort" is the French name for the city of Frankfurt, home of Deutsche Bundesbank. This alignment of French and (West) German monetary policy was crucial for establishing the minimum economic preconditions needed for the creation of the EMU that was designed in Maastricht.

The EMU would undergo a crisis before the ratification of the Maastricht Treaty was complete, however the Member States managed through what at the time seemed like ad hoc solutions to overcome this situation and turn the euro into a success story. ${ }^{9}$

Of course, becoming a "success story" did not mean the elimination of all of the problems. In the very early stages (i.e. the first and second phases of the creation of the institutional framework for the future Eurozone), both the convergence criteria and their application attracted criticisms. At the time, these criticisms were overcome through political will, and the Eurozone went ahead even including Greece in its borders.

More than a decade later, some elements of the criticisms of the mid-1990s have proven to be accurate: the Eurozone has entered into a serious crisis and certain members have been hit particularly hard. In the short run, this may be seen as a major failure of European economic policy and European politics. Responses have, however, been considerably delayed - this is especially clear when we recall that critics in the 1990s warned of most of the problems that had surfaced by $2010 .{ }^{10}$

Nevertheless, the steps taken - even if delayed - have allowed us to avoid the worst case scenario (the collapse of the Eurozone) using new financing tools and mechanisms. This system is, of course, still far from ready but there are increasingly precise plans in place for its completion. Moreover, it has allowed for the continued operation of the Eurozone, already with slowly decreasing risks.

8 Created in 1979, the ECU was a basket of European Community Member States' currencies, which served as the official unit of account of the European Community until 1 January 1999 when the euro was introduced.

9 For a brief analysis of the history of the EMU from the Maastricht Treaty to 2017, see Lehmann - Umbach (2017).

10 It is very interesting to reread the so-called Schäuble-Lamers paper [Überlegungen zur europäischen Politik 1994] in light of the dramatic EMU crisis of 2010 since by this date, several key problems described in the paper had come to pass, and they were not limited to the EMU. The paper makes for illuminating reading today given the broader contexts it considered. On the topic of potential approaches (including differentiated or multi-speed integration), many of the points raised are still worthy of reflection. Significantly, one of the unnamed authors, Wolfgang Schäuble has recently written another document which presents his ideas on the future system for the EMU. See Non-paper for paving the way towards a Stability Union (2017) (Schäuble's authorship is also uncredited in this document). 
During this recent history of the Eurozone, the role of the Member States has been especially important from two standpoints. First, it has become very clear to everyone that the performance and approach (or philosophy) of the Member States remain crucial even in the thoroughly regulated field of European (economic) policy. Second, significant differences have appeared regarding the Member States' involvement in the new financial solutions and mechanisms aimed at stabilising the Eurozone.

This second fact, in particular, confirms that there are important differences in the Member States' interests and that the European Union can accept these differences. In this vein, differentiated integration is seen and acknowledged as a way forward - even in an integrated field where the choice to opt out was frozen decades ago.

\section{Today's Challenges: How to Proceed?}

In recent years, the news has been full of the challenges facing the European Union. These challenges include issues that have been well-known for some time and are largely economic in nature (e.g. insufficient social and territorial cohesion, problems concerning European growth and competitiveness, the Eurozone crisis) as well as others that have even broader implications and are at least partially new (e.g. mass immigration and its demographic consequences, the lack of any real strategy regarding the broadly defined EU neighbourhood, the problem of Brexit and other potential "xxxits"). ${ }^{11}$

These challenges are often presented in the news and debates as issues that the European Union cannot deal with appropriately. This may be true at a given moment, and, of course, in the case of certain issues, we cannot be sure of future developments. However, I would argue that it is very important to approach these challenges as opportunities. They are, in particular, opportunities that promote changes - in institutional design, in strategies, in policies, in operating procedures - which would be needed in any case but could not attract sufficient political support without external pressure.

Of course, it is vital that the EU28 or at least a critical mass of Member States recognise(s) this need for political support in due time. A too slow and/or too weak response could cause serious or even fatal damage. But if the worst case scenario is avoided - and we should not forget that the European integration process has managed to avert this outcome over the course of many difficult situations in its first 65 years - then these experiences and adaptations can strengthen the process.

11 Significantly, there is currently far less news coverage about the successes of the integration process. Even when news stories state the facts about European integration correctly, the news is often cast in a negative light. For more details about this trend and the relationship between these kinds of communications and the definition of a mission, see Szemlér (2009), pp.130-131. 
This broad approach should be borne in mind even in situations where various Member States propose different solutions to particular issues. These challenges should be seen as opportunities to reform (or, if necessary, even radically change) traditional policies and approaches in the fields they directly or even indirectly concern.

In the spring of 2017, on the occasion of the 60th anniversary of the Treaties of Rome, the European Commission began to make public its evaluation of the state of the European Union, outlining different scenarios for the future integration process.

In this vein, the Commission published its "White Paper on the Future of Europe" on 1 March 2017. This document addressed the current state of European integration along with major challenges to the process. It also set out five different scenarios for future development up to $2025^{12}$ and described the major potential consequences of associated development paths. Table 1 summarises these consequences in some of the most important areas of integration.

\section{Table 1: Five scenarios: A policy overview}

\begin{tabular}{|c|c|c|c|c|c|}
\hline & "Carry on" & $\begin{array}{c}\text { "Nothing but } \\
\text { the single } \\
\text { market" }\end{array}$ & $\begin{array}{c}\text { "Those who } \\
\text { want more do } \\
\text { more" }\end{array}$ & $\begin{array}{c}\text { "Do less more } \\
\text { efficiently" }\end{array}$ & $\begin{array}{l}\text { "Do far more } \\
\text { together" }\end{array}$ \\
\hline $\begin{array}{l}\text { Single market \& } \\
\text { trade }\end{array}$ & $\begin{array}{l}\text { The single } \\
\text { market is } \\
\text { strengthened, } \\
\text { including in } \\
\text { the energy and } \\
\text { digital sectors; } \\
\text { the EU27 } \\
\text { pursue pro- } \\
\text { gressive trade } \\
\text { agreements. }\end{array}$ & $\begin{array}{l}\text { The single mar- } \\
\text { ket for goods } \\
\text { and capital is } \\
\text { strengthened; } \\
\text { standards con- } \\
\text { tinue to differ; } \\
\text { the free move- } \\
\text { ment of people } \\
\text { and services is } \\
\text { not fully gua- } \\
\text { ranteed. }\end{array}$ & $\begin{array}{l}\text { As in the "Car- } \\
\text { ry on" scenario, } \\
\text { the single } \\
\text { market is } \\
\text { strengthened } \\
\text { and the EU27 } \\
\text { pursue pro- } \\
\text { gressive trade } \\
\text { agreements. }\end{array}$ & $\begin{array}{l}\text { Common } \\
\text { standards } \\
\text { are set to a } \\
\text { minimum but } \\
\text { enforcement is } \\
\text { strengthened } \\
\text { in areas regula- } \\
\text { ted at EU level; } \\
\text { trade is dealt } \\
\text { with exclusive- } \\
\text { ly at EU level. }\end{array}$ & $\begin{array}{l}\text { The single } \\
\text { market is } \\
\text { strengthened } \\
\text { through har- } \\
\text { monisation of } \\
\text { standards and } \\
\text { stronger enfor- } \\
\text { cement; trade } \\
\text { is dealt with } \\
\text { exclusively at } \\
\text { EU level. }\end{array}$ \\
\hline $\begin{array}{l}\text { Economic \& Mo- } \\
\text { netary Union }\end{array}$ & $\begin{array}{l}\text { Incremental } \\
\text { improvements } \\
\text { are made to } \\
\text { the functio- } \\
\text { ning of the } \\
\text { euro area. }\end{array}$ & $\begin{array}{l}\text { Cooperation in } \\
\text { the euro area } \\
\text { is limited. }\end{array}$ & $\begin{array}{l}\text { As in the } \\
\text { "Carry on" sce- } \\
\text { nario; an ex- } \\
\text { ception applies } \\
\text { to a group of } \\
\text { countries who } \\
\text { deepen coope- } \\
\text { ration in areas } \\
\text { such as taxati- } \\
\text { on and social } \\
\text { standards. }\end{array}$ & $\begin{array}{l}\text { Several steps } \\
\text { are taken to } \\
\text { consolidate } \\
\text { the euro area } \\
\text { and ensure its } \\
\text { stability; the } \\
\text { EU27 are less } \\
\text { active in some } \\
\text { aspects of em- } \\
\text { ployment and } \\
\text { social policy. }\end{array}$ & $\begin{array}{l}\text { An economic, } \\
\text { financial and } \\
\text { fiscal Union is } \\
\text { achieved, as } \\
\text { envisaged in } \\
\text { the report of } \\
\text { the Five Presi- } \\
\text { dents of June } \\
2015 \text {. }\end{array}$ \\
\hline
\end{tabular}

12 According to the subtitle of this document, it presented "[r]eflections and scenarios for the EU27 by $2025^{\prime \prime}$ - as such, it considered Brexit to be a (future) fact. 


\begin{tabular}{|c|c|c|c|c|c|}
\hline & "Carry on" & $\begin{array}{c}\text { "Nothing but } \\
\text { the single } \\
\text { market" }\end{array}$ & $\begin{array}{l}\text { "Those who } \\
\text { want more do } \\
\text { more" }\end{array}$ & $\begin{array}{l}\text { "Do less more } \\
\text { efficiently" }\end{array}$ & $\begin{array}{l}\text { "Do far more } \\
\text { together" }\end{array}$ \\
\hline $\begin{array}{l}\text { Schengen, } \\
\text { migration \& } \\
\text { security }\end{array}$ & $\begin{array}{l}\text { Cooperation } \\
\text { is gradually } \\
\text { stepped up } \\
\text { around ex- } \\
\text { ternal border } \\
\text { management; } \\
\text { progress is } \\
\text { made on esta- } \\
\text { blishing a co- } \\
\text { mmon asylum } \\
\text { system; there } \\
\text { is improved } \\
\text { coordination } \\
\text { around securi- } \\
\text { ty matters. }\end{array}$ & $\begin{array}{l}\text { No single } \\
\text { migration or } \\
\text { asylum policy } \\
\text { unites the } \\
\text { EU27; further } \\
\text { security co- } \\
\text { ordination is } \\
\text { dealt with bila- } \\
\text { terally; internal } \\
\text { border cont- } \\
\text { rols are more } \\
\text { systematic. }\end{array}$ & \begin{tabular}{|l} 
As in the \\
"Carry on" sce- \\
nario; an ex- \\
ception applies \\
to a group of \\
countries who \\
deepen coope- \\
ration around \\
security and \\
justice matters.
\end{tabular} & $\begin{array}{l}\text { There is } \\
\text { systematic } \\
\text { cooperation } \\
\text { around border } \\
\text { management, } \\
\text { asylum policies } \\
\text { and counter- } \\
\text {-terrorism } \\
\text { matters. }\end{array}$ & $\begin{array}{l}\text { As in the "Do } \\
\text { less more } \\
\text { efficiently" } \\
\text { scenario, there } \\
\text { is systematic } \\
\text { cooperation } \\
\text { around border } \\
\text { management, } \\
\text { asylum policies } \\
\text { and counter- } \\
\text {-terrorism } \\
\text { matters. }\end{array}$ \\
\hline $\begin{array}{l}\text { Foreign policy } \\
\text { \& defence }\end{array}$ & $\begin{array}{l}\text { Progress is } \\
\text { made towards } \\
\text { speaking with } \\
\text { one voice on } \\
\text { foreign affairs } \\
\text { issues; there is } \\
\text { closer defence } \\
\text { cooperation. }\end{array}$ & $\begin{array}{l}\text { Some foreign } \\
\text { policy issues } \\
\text { are increasin- } \\
\text { gly dealt with } \\
\text { bilaterally; } \\
\text { defence coope- } \\
\text { ration remains } \\
\text { as it is today. }\end{array}$ & $\begin{array}{l}\text { As in the } \\
\text { "Carry on" sce- } \\
\text { nario; an ex- } \\
\text { ception applies } \\
\text { to a group of } \\
\text { countries who } \\
\text { deepen their } \\
\text { defence coope- } \\
\text { ration with a } \\
\text { focus on mili- } \\
\text { tary coordina- } \\
\text { tion and joint } \\
\text { equipment }\end{array}$ & $\begin{array}{l}\text { The EU speaks } \\
\text { with one voice } \\
\text { on all foreign } \\
\text { policy issues; } \\
\text { the European } \\
\text { Defence Union } \\
\text { is created }\end{array}$ & $\begin{array}{l}\text { As in the "Do } \\
\text { less more } \\
\text { efficiently" } \\
\text { scenario, the } \\
\text { EU speaks } \\
\text { with one voice } \\
\text { on all foreign } \\
\text { policy issues; } \\
\text { the European } \\
\text { Defence Union } \\
\text { is created }\end{array}$ \\
\hline EU budget & $\begin{array}{l}\text { Part of the } \\
\text { budget is } \\
\text { updated to } \\
\text { reflect the } \\
\text { reform agenda } \\
\text { agreed on by } \\
\text { the EU27. }\end{array}$ & $\begin{array}{l}\text { The budget is } \\
\text { refocused on } \\
\text { essential finan- } \\
\text { cial operations } \\
\text { needed for the } \\
\text { single market. }\end{array}$ & $\begin{array}{l}\text { As in the "Car- } \\
\text { ry on" scena- } \\
\text { rio; additional } \\
\text { budgets are } \\
\text { made available } \\
\text { by some Mem- } \\
\text { ber States in } \\
\text { the areas whe- } \\
\text { re they decide } \\
\text { to do more. }\end{array}$ & $\begin{array}{l}\text { The budget is } \\
\text { significantly } \\
\text { redesigned } \\
\text { to fit the new } \\
\text { priorities agre- } \\
\text { ed on at EU27 } \\
\text { level. }\end{array}$ & $\begin{array}{l}\text { The budget is } \\
\text { significantly } \\
\text { updated and } \\
\text { increased, } \\
\text { backed up } \\
\text { by the EU27's } \\
\text { own resources; } \\
\text { there is euro } \\
\text { area fiscal sta- } \\
\text { bilisation. }\end{array}$ \\
\hline $\begin{array}{l}\text { Capacity to } \\
\text { deliver }\end{array}$ & $\begin{array}{l}\text { A positive } \\
\text { agenda of } \\
\text { actions yields } \\
\text { concrete re- } \\
\text { sults; the de- } \\
\text { cision-making } \\
\text { process re- } \\
\text { mains complex } \\
\text { to grasp; the } \\
\text { capacity to de- } \\
\text { liver does not } \\
\text { always match } \\
\text { expectations. }\end{array}$ & $\begin{array}{l}\text { The decisi- } \\
\text { on-making } \\
\text { process may } \\
\text { be easier to } \\
\text { understand } \\
\text { but the ca- } \\
\text { pacity to act } \\
\text { collectively is } \\
\text { limited; issues } \\
\text { of common } \\
\text { concern often } \\
\text { need to be sol- } \\
\text { ved bilaterally. }\end{array}$ & $\begin{array}{l}\text { As in the } \\
\text { »Carry on« } \\
\text { scenario, a } \\
\text { positive agen- } \\
\text { da of EU27 } \\
\text { actions yields } \\
\text { results; some } \\
\text { groups achieve } \\
\text { more together } \\
\text { in certain } \\
\text { domains; the } \\
\text { decision-ma- } \\
\text { king process } \\
\text { becomes more } \\
\text { complex. }\end{array}$ & $\begin{array}{l}\text { Reaching initial } \\
\text { agreement } \\
\text { about tasks to } \\
\text { prioritise or } \\
\text { give up is cha- } \\
\text { llenging; once } \\
\text { in place, the } \\
\text { decision-ma- } \\
\text { king process } \\
\text { may be easier } \\
\text { to understand; } \\
\text { the EU acts } \\
\text { faster and } \\
\text { more decisive- } \\
\text { ly when it has } \\
\text { a greater role. }\end{array}$ & $\begin{array}{l}\text { Decision-ma- } \\
\text { king happens } \\
\text { faster and } \\
\text { enforcement } \\
\text { is stronger } \\
\text { across the } \\
\text { board; questi- } \\
\text { ons of account- } \\
\text { ability arise for } \\
\text { some who feel } \\
\text { that the EU } \\
\text { has taken too } \\
\text { much power } \\
\text { away from the } \\
\text { Member States. }\end{array}$ \\
\hline
\end{tabular}

Source: European Commission 2017a:29. 
As this table shows, the five scenarios presented in the White Paper could lead to very different results by 2025. These scenarios span a wide range of possibilities from a "minimalist" approach ("Nothing but the single market") to an idealistic future vision ("Doing much more together"). The three scenarios in between these poles reflect compromises in different respects: "Carrying on" describes the continuation of the European Union's current course of action with all the results and comforts but also all the problems of the status quo; "Doing less more efficiently" means focusing on (and therefore presumably making more progress in) fewer areas than is currently the case; "Those who want more do more" is a scenario that opens the way for multi-speed integration.

Significantly, all these scenarios refer to future actions. This means that pursuing the "Nothing but the single market" option, for example, would not destroy the EMU's achievements to date, but it also does not foresee any substantial progress in this field. A lack of progress could, however, endanger effective European integration in any area. The example of EMU is extremely interesting in this respect; the crisis which hit the Union in 2010 clearly reveals the realistic nature of this risk.

In fact, this danger might apply to any of the areas where European integration has led to considerable achievements since the 1950s. We should also note that some challenges could result in crises in other areas where no such results (no European policies or joint actions) have previously been seen. The most striking example is the mass immigration issue where brutal Europe-wide debates have caused not "only" intra-EU debates but the significant strengthening of radical political ideas and corresponding parties in a number of Member States.

The importance and, thus, the main message of these remarks, is that "carrying on" would not mean maintaining our current situation. The challenges that we face make this impossible. Similarly, "Nothing but the single market" and "Doing less more efficiently" represent only partial responses (responses to challenges in one or just a few fields). "Doing much more together" seems politically unfeasible given the experiences of the last two decades. ${ }^{13}$

The White Paper had the merit of presenting the options (scenarios) very clearly while also highlighting some of the major potential consequences of these choices. Nevertheless, on its own, it was not the outline of a new strategy: rather, it was a new approach calling for a potentially wide-ranging political debate.

The White Paper was followed by several "Reflection Papers," which dealt in more detail with some of the key issues and challenges of European integration. Published between April and June 2017, these documents tackled the following issues in the order listed: social affairs, globalisation, the EMU, defence

13 The EMU may be understood as the last major European "project" that had the potential to include all Member States. Exercising their choice to opt out, the United Kingdom and Denmark became de jure exceptions to the rules; for all other Member States, joining the Eurozone was a question of timing (dependent on their ability or readiness to do so). 
and EU finances (the EU budget) (European Commission 2017b, 2017c, 2017d, 2017e and 2017f).

The Reflection Papers on social affairs and EU finances applied the five scenarios in the White Paper under the same or similar names. In contrast, the Reflection Paper on defence outlined three scenarios whose scope differed from the scenarios in the White Paper. The remaining two Reflection Papers addressed the EMU and globalisation respectively, focusing in the first case on the means of completing the "project" and in the second on opportunities and the further steps needed to harness the effects of globalisation.

The differences in the structures of these papers should not be seen as a problem. On the contrary, it makes visible the differences in the potential courses of action that are open to the European Union in different fields. The White Paper and the Reflection Papers together provide a solid basis for reflection as well as political and public debate. The European Commission has, thus, done its homework by presenting this initiative. From this point onwards, it will fall to Member States' representatives - of course, acting together with and within European Union institutions - to agree on strategies, inform and convince the public, make concrete plans and take the necessary steps.

It was because of the obvious need for political backing from the Member States that 2017 was such a keenly anticipated year. Aside from several other major events, elections in the two biggest Member States - in France and Germany - were considered crucial for the future of European integration.

In both these states, big changes were not ruled out in the months before the election. In France, where some candidates had proposed abandoning the euro and returning to the franc among other anti-EU ideas, tensions ran very high at the beginning of 2017. In Germany, the chancellor's stance on mass immigration attracted strong criticisms, and at the start of 2017, the race between her and her main opponent looked wide open. This situation brought great uncertainty to a European Union that was still reeling from the shock of the Brexit referendum in the previous year.

Ultimately, the outcome of both elections proved to be calming from the points of view of most supporters of continued European integration (even if the new German government has not yet been formed): Emmanuel Macron and Angela Merkel emerged as the leaders of France and Germany, respectively. The most important tasks for these leaders include coordinating - and along with the leaders of other Member States - ensuring the required political groundwork for reforms, conceiving of a new vision (mission) with all its key elements and taking the first steps towards realising this vision.

Back in the summer of 2017, an exchange of ideas was begun between the newly elected French president and the German chancellor seeking re-election. Of course, given the difference between their situations at the time, it was the French president who took the more active role in this dialogue. His initiatives 
addressed many aspects of the European integration project and were generally received positively if cautiously by his German partner, with discussion of the details being deferred until after the German elections.

Just two days after the German elections, when he was already aware of Merkel's victory, Macron delivered a key speech at the Sorbonne. This presentation emphasised the need for the "re-foundation of Europe" and outlined a vision of Europe both in general terms (see Box 2) and more detail (Macron 2017).

\section{Box 2: Thoughts on the mission of the European integration process in 2017}

Excerpt from a speech by Emmanuel Macron on 26 September 2017:

“The time for France to make proposals has returned. I'm thinking right now of Robert Schuman, who, in Paris on 9 May 1950, was bold enough to propose building Europe. I remember his powerful words: 'A united Europe was not achieved and we had war.'

So today, I take responsibility for making proposals, forging further ahead, being bold enough to talk about Europe and finding words of affection and ambition for it again. Not imposing, forcing or seeking to reinvent everything - many things have already been said - but taking the risk of proposing a coherent, ambitious vision, proposing a way forward, an objective, rather than discussing instruments, and taking the vital risk of proposing initiatives. Two days after our main partner's elections I want again to congratulate Federal Chancellor Merkel, whom I look forward to going on working with because we share the same European commitment, and I know her commitment to Europe. [...]

So first of all I am making the proposal to Germany for a new partnership. We will not agree on everything, or straight away, but we will discuss everything. To those who say that is an impossible task, I reply: you may be used to giving up; I am not. To those who say it is too difficult, I say: think of Robert Schuman five years after a war, from which the blood was barely dry. On all the issues I have talked about, France and Germany can inject decisive, practical momentum. [...] Let's produce another Élysée Treaty on 22 January next year.

[...] I have met 22 of my counterparts over the past few months; I want to work with every one of them, humbly but with determination, because this is our moment.

France's time for making proposals has returned, so I will be making proposals to everyone who shares this desire for a sovereign Europe, based on the central objectives I have mapped out: the desire for a united, differentiated Europe, for a democratic Europe supporting the conventions initiative, for launching in the next few weeks a group for the refoundation of Europe. This group will include representatives of each participating Member State and will involve European institutions."

Source: Macron 2017: 23-24.

One very important aspect of this vision of the future integration process was its positive approach to potential differences and refusal to exclude any Member States:

[L] et's embrace the differentiations, the vanguard, the heart of Europe I was talking about earlier. We've got to make progress on all our major challenges, quickening the pace and setting our sights higher. No State must be excluded from the process, but no country must be able to block those wanting to make faster progress or forge further ahead (Macron 2017: 23) 
At the time of writing (late autumn of 2017), far more reforms have been put forward than was the case a year ago. At that time, we were still dealing with the fresh shock of the Brexit referendum and uncertainties around France and Germany along with an external factor, the unexpected outcome of US elections, which injected yet another element of uncertainty. Currently, however, there is good news: the French and German elections (and even the less internationally significant Dutch contest) have brought some calm to the supporters of the European integration process. Moreover, despite some turbulence, the relationship with the new US administration is still functional. It is now up to the leaders of the Member States to use this opportunity to move ahead.

\section{Concluding remarks}

The previous parts of this article have discussed the importance of challenges and the need to have a mission. I have also highlighted a compelling example from the history of European integration to support these ideas. Finally, I have stressed the need to overcome the stalemate that the European integration process has found itself in since the mid-2010s and outlined the road maps presented by the European Commission in 2017.

In order to proceed with the options on the table, we will need to open up an EU-wide political discussion of these topics and set priorities - which will surely also require some compromises. This exercise must be different from the public consultations held on various topics in the past: while the spirit of those consultations (an openness to new ideas) should be retained, these new talks should lead to decisions about overall priorities and specific objectives. Based on the results of this process, new mechanisms - meaning not only financial instruments but also preconditions for institutional operations - can and should be added to policies at the corresponding (local, regional, country-, country-group, EU-) level. Efforts must be made at all levels to respond to the specific problem rather than a (supposed) proxy for that problem. To ensure this happens, we will need to rediscover the principle of subsidiarity and apply it in practice.

It is clear that given the differences in Member States' positions and their readiness to deepen integration in specific areas, the outlined approach raises the prospect of multi-speed integration - an idea also suggested in the European Commission's proposals. For those who still fear this process, we would stress that based on the current depth of integration and the many and very different Member States involved, it is the only realistic path forward.

Multi-speed integration is already under way but this is not a disaster. The true disaster would be if the integration project were discarded for the sake of the unrealistic goal of maintaining an already non-existent uniformity.

If the European Union and its Member States are to face challenges and survive unscathed as possible, they will need to use and develop already exist- 
ing elements of flexibility. Of course, the choice to intensify integration in any area should remain open to any Member State that is willing and able to commit to this development. Ultimately, it is the willingness and ability of these states that will decide the future of the integration process.

So long as the very important condition of openness is fulfilled, recognising and adapting to differences when planning future steps will not bring an end to European integration. To the contrary, this may be the only way to rise successfully to serious challenges and even crises and - by surviving and learning from them - become stronger and better prepared for challenges to come.

\section{References}

Caraffini, Paolo (2015): De Gaulle, the "Empty Chair Crisis" and the European Movement, Perspectives on Federalism, Vol. 7, issue 2, 2015, Centro Studi sul Federalismo, Moncalieri: available at http://www.on-federalism.eu/attachments/219_download.pdf (28 October 2017).

Council-Commission of the European Communities (1970): Report to the Council and the Commission on the realization by stages of economic and monetary union the Community, Supplement to Bulletin 11-1970 of the European Communities: available at http://aei.pitt. edu/1002/1/monetary_werner_final.pdf (28 October 2017).

Council of the European Economic Community (1966): Final Communiqué of the extraordinary session of the Council, Luxembourg, 17 to 18 and 28 to 29 January 1966, Bulletin of the European Communities, March 1966, 3-66, pp. 5-11: available at http://www.internationaldemocracywatch.org/attachments/297_Luxembourg\%20Compromise.pdf (28 October 2017).

European Commission (2017a): White Paper on the Future of Europe. Reflections and scenarios for the EU27 by 2025, European Commission, Brussels, 1 March 2017: available at https:// ec.europa.eu/commission/sites/beta-political/files/white_paper_on_the_future_of_europe_en.pdf (27 March 2017).

European Commission (2017b): Reflection Paper on the Social Dimension of Europe, European Commission, Brussels, 26 April 2017: available at https://ec.europa.eu/commission/sites/beta-political/files/reflection-paper-social-dimension-europe_en.pdf (30 October 2017).

European Commission (2017c): Reflection Paper on harnessing globalisation, European Commission, Brussels, 10 May 2017: available at https://ec.europa.eu/commission/sites/beta-political/ files/reflection-paper-globalisation_en.pdf (30 October 2017).

European Commission (2017d): Reflection Paper on the Deepening of the Economic and Monetary Union, European Commission, Brussels, 31 May 2017: available at https://ec.europa.eu/ commission/sites/beta-political/files/reflection-paper-emu_en.pdf (1 July 2017).

European Commission (2017e): Reflection Paper on the Future of European Defence, European Commission, Brussels, 28 June 2017: available at https://ec.europa.eu/commission/sites/beta-political/files/reflection-paper-defence_en.pdf (31 October 2017). 
European Commission (2017f): Reflection Paper on the Future of EU Finances, European Commission, Brussels, 28 June 2017: available at https://ec.europa.eu/commission/sites/beta-political/ files/reflection-paper-eu-finances_en.pdf (30 June 2017).

Lehmann, Wilhelm - Umbach, Gaby (2017): EMU - 25 Years after Maastricht: Historical Challenges, Economic Ideas, Political Solutions, European University Institute, Robert Schuman Centre for Advanced Studies, Policy Brief 2017/18, July 2017, Florence: available at http://cadmus. eui.eu/bitstream/handle/1814/47404/RSCAS_PB_2017_18.pdf?sequence=1 \& isAllowed=y (30 October 2017).

Macron, Emmanuel (2017): Initiative for Europe. Speech by M. Emmanuel Macron, President of the French Republic, Paris, 26 September 2017: available at https://www.diplomatie.gouv. $\mathrm{fr} / \mathrm{IMG} / \mathrm{pdf} /$ english_version_transcript_-_initiative_for_europe_-_speech_by_the_president_of_the_french_republic_cle8de628.pdf (27 October 017).

Non-paper for paving the way towards a Stability Union (2017): available at http://media2.corriere.it/corriere/pdf/2017/non-paper.pdf (14 October 2017).

Mongelli, Francesco Paolo (2008): European economic and monetary integration and the optimum currency area theory, European Economy, Economic Papers No. 302, February 2008, European Commission, Brussels: available at http://ec.europa.eu/economy_finance/publications/pages/publication12081_en.pdf (18 October 2017).

Schuman, Robert (1950): Declaration of 9th May 1950, in: European Issue No. 204, 10th May 2011, Fondation Robert Schuman: available at https://www.robert-schuman.eu/en/doc/questions-d-europe/qe-204-en.pdf (17 October 2017).

Szemlér, Tamás (2009): Future Prospects of the European Union, in: Revista de Economía Mundial, No. 22, 2009, pp. 127-138: available at http://www.redalyc.org/pdf/866/86611893007.pdf (31 October 2017).

Überlegungen zur europäischen Politik (1994), 1 September: available at http://www.bundesfinanzministerium.de/Content/DE/Downloads/schaeuble-lamers-papier-1994.pdf? blob=publicationFile \& v=1 (29 October 2017).

Tamás Szemlér, Ph.D, is an economist, French language instructor and associate professor at the Faculty of International and European Studies of the National University of Public Service (Budapest) where he has worked since September 2016. Between 1993 and 2010, he was a researcher at the Hungarian Academy of Science's Institute for World Economics (IWE) where he also served as Deputy Director (responsible for scientific affairs) from 2008 to 2009. Between 2009 and 2016, Dr. Szemlér was an associate professor at the Faculty of International Management and Business of Budapest Business School and also held posts as Head of the Department of Economics (2009-2014) and Dean of the Faculty of International Management and Business (2012-2016). Dr. Szemlér is the author of more than 140 publications. His research and teaching work focus on deepening ties within the European Union as well as its enlargement and external (economic and political) relations.E-mail: szemler.tamas@uni-nke.hu. 